\title{
Iowa Congressional Delegation and the Great Economic Issues, 1929-1933
}

\author{
David L. Porter
}

$\mathrm{H}$

ISTORIANS writing about the Great Depression have paid relatively little attention to the response of the rural, agrarian Middle West to vital economic legislation. ${ }^{1}$ For example, how did Iowa, the state in which President Herbert Hoover was born, view crucial national economic problems? An analysis of votes cast by the lowa congressional delegation during the Republican Hoover administration reveals several generalizations about their reactions to major measures aiding business, benefiting organized labor, providing federal unemployment relief, and expanding government competition with private industry. ${ }^{2}$

I am indebted to the National Endowment for the Humanities for financial assistance in researching this topic at the Hoover Library, the University of Iowa Library, and the State Historical Society of Iowa.

1. James T. Patterson, The New Deal and the States: Federalism in Transition (Princeton, 1969) and Paul E. Mertz, New Deal Policy and Southern Rural Poverty (Baton Rouge, 1978) discuss the response to national reform programs at the state and local levels during the Great Depression.

2. Business measures examined are the Smoot-Hawley Tariff Act of 1930 and the Reconstruction Finance Corporation Act of 1932; the labor legislation 
Between 1929 and 1933, the Iowa congressional delegation usually supported bills helping business and organized labor. On the other hand, it usually resisted federal unemployment relief and increased government control over private enterprise. Economic considerations prevailed among lowa senators and representatives, with political motivations playing a subordinate role. The Iowa congressional delegation, however, comprised a mixture of progressives, moderates, and conservatives, who clashed fairly often on fundamental economic measures. And, finally, Iowa senators and representatives were less conservative than anticipated, frequently demonstrating more progressivism than President Hoover on the great economic issues.

Republicans dominated the lowa congressional delegation. ${ }^{3}$ (See Table 1) Between 1929 and 1931, Hoover's party held all eleven House seats and one Senate position. Republicans continued to prevail the next two years, occupying ten House and both Senate seats. Democrats wielded negligible power, with Senator Steck and Representative Jacobsen the only party members in the Iowa delegation.

Despite serving a moderately populated, predominantly

studies include the Immigration Restriction Bill of 1931, the Norris-La Guardia Act of 1932, and the sales-tax provision of the Revenue Act of 1932. The La Follette-Costigan, Garner, and Wagner bills of 1932 are the federal unemployment relief measures examined, while the Muscle Shoals Bill of 1930 is the principal legislation enhancing federal competition with private industry. For background on Hoover and/or Congress see: David Burner, Herbert Hoover: A Public Life (New York, 1978); Joan Hoff Wilson, Herbert Hoover: A Forgotten Progressive (Boston, 1975); Jordan A. Schwarz, The Interregnium of Despair: Hoover, Congress and the Depression (Urbana, 1970); Ellis W. Hawley, The Great War and the Search for a Modern Order: $A$ History of the American People and their Institutions (New York, 1979); Martin L. Fausold and George T. Mazuzan, eds., Herbert Hoover and the Crisis of American Capitalism (Cambridge, MA, 1973); Albert U. Romasco, The Poverty of Abundance: Hoover, the Nation, and the Depression (New York, 1965); and Harris G. Warren, Herbert Hoover and the Great Depression (New York, 1959).

3. Mildred Throne, "Iowans in Congress, 1847-1953," lowa Journal of History 51 (1953): 329-368; Biographical Directory of the American Congress, 1774-1971 (Washington, D.C., 1971); Philip A. Grant, Jr., "Iowa Congressional Leaders, 1921-1932," Annals of lowa 42 (Fall 1974):430-442. 
TABLE 1

Members of lowa Delegation, 1929-1933

\begin{tabular}{|c|c|c|c|c|}
\hline Member & Party & Chamber & Years & Hometown \\
\hline $\begin{array}{l}\text { Smith } W . \\
\text { Brookhart }\end{array}$ & Republican & Senate & $\begin{array}{l}1922-1925 \\
1927-1933\end{array}$ & Washington \\
\hline Ed H. Campbell & Republican & House & $1929-1933$ & Battle Creek \\
\hline Cyrenus Cole & Republican & House & $1921-1933$ & Cedar Rapids \\
\hline Lester J. Dickinson & Republican & $\begin{array}{l}\text { House } \\
\text { Senate }\end{array}$ & $\begin{array}{l}1919-1931 \\
1931-1937\end{array}$ & Algona \\
\hline Cassius C. Dowell & Republican & House & $\begin{array}{l}1915-1935 \\
1937-1940\end{array}$ & Des Moines \\
\hline Fred C. Gilchrist & Republican & House & $1931-1945$ & Laurens \\
\hline $\begin{array}{l}\text { Gilbert N. Haugen } \\
\text { Bernhard M. }\end{array}$ & Republican & House & $1899-1933$ & Northwood \\
\hline Jacobsen & Democrat & House & $1931-1936$ & Clinton \\
\hline William F. Kopp & Republican & House & $1921-1933$ & Mt. Pleasant \\
\hline $\begin{array}{l}\text { Fred D. Letts } \\
\text { C. William }\end{array}$ & Republican & House & $1925-1931$ & Davenport \\
\hline $\begin{array}{l}\text { Ramseyer } \\
\text { Thomas J. B. }\end{array}$ & Republican & House & $1915-1933$ & Bloomfield \\
\hline Robinson & Republican & House & $1923-1933$ & Hampton \\
\hline Daniel F. Steck & Democrat & Senate & $1926-1931$ & Ottumwa \\
\hline $\begin{array}{l}\text { Charles E. } \\
\text { Swanson } \\
\text { Lloyd Thurston }\end{array}$ & $\begin{array}{l}\text { Republican } \\
\text { Republican }\end{array}$ & $\begin{array}{l}\text { House } \\
\text { House }\end{array}$ & $\begin{array}{l}1929-1933 \\
1925-1939\end{array}$ & $\begin{array}{l}\text { Council Bluffs } \\
\text { Osceola }\end{array}$ \\
\hline
\end{tabular}

rural state, the Iowa congressional delegation had considerable political clout on Capitol Hill. In the Senate, the flamboyant Brookhart vigorously defended agriculture and organized labor and often made vitriolic attacks on big business. Representative Haugen, serving in Congress since 1899, chaired the prestigious Agriculture Committee and sponsored numerous farm measures. House colleagues regarded Congressmen Dickinson and Ramseyer as financial experts and Representative Cole as an authority on international affairs. Congressman Swanson belonged to the influential Judiciary Committee, while Representative Thurston served on the powerful Rules Committee. ${ }^{4}$

4. For a pertinent memoir, see Cyrenus Cole, I Remember I Remember (Iowa City, 1936). There unfortunately are no published biographies of Iowa senators and representatives from the Hoover era, but George W. McDaniel is 
The Iowa congressional delegation resoundingly adopted the Smoot-Hawley Act of 1930 aiding big business. Besides raising business tariff duties to an unprecedented 40 percent level, the Smoot-Hawley measure nearly doubled protection for agricultural commodities. ${ }^{5}$ With the exception of Representative Campbell, Iowa congressmen welcomed the rate changes. (See Table 2) Ramseyer even battled in the Ways and Means Committee to increase protection for midwestern farmers, while Cole urged President Hoover to "make very speedy disposition" of the tariff measure. "If there is too much delay," Cole warned, "it will get on the nerves of the people and create unlimited propaganda which may be quite as embarrassing as the senatorial debates have been." 6

Excitement about potential economic benefits for Iowa farmers induced the state's representatives to endorse the

preparing one of Smith Wildman Brookhart and Peter T. Harstad and Bonnie Michael are collaborating on one of Gilbert $N$. Haugen. There are numerous unpublished studies of Senator Brookhart, including Ray S. Johnston, "Smith Wildman Brookhart: Iowa's Last Populist" (M.A. thesis, Iowa State Teacher's College, 1964); George W. McDaniel, "Over Here: The Mobilization of the Republican Service League to Defeat Smith Wildman Brookhart" (M.A. essay, University of Iowa, 1977); Corwin D. Cornell, "Smith W. Brookhart and Agrarian Discontent in Iowa" (M.A. thesis, University of Iowa, 1948); Barry A. Russell, "The Changing Concept of Iowa Progressivism: Smith W. Brookhart vs. Albert B. Cummins, 1920-26" (M.A. thesis, University of North Carolina, 1973); Cornelius Holland Bull III, "Smith Wildman Brookhart-Neither God nor Little Fish" (Senior thesis, Princeton University, 1950). For published works on Brookhart, see: Reinhard H. Luthin, "Smith Wildman Brookhart of Iowa: Insurgent Agrarian Politician," Agricultural History 25 (October 1951): 187-197; George W. McDaniel, "Prohibition Debate in Washington County, 1890-1894: Smith Wildman Brookhart's Introduction to Politics," The Annals of Iowa 45 (Winter 1981): 519-536; Jerry Neprash, The Brookhart Campaigns in lowa, 1920-1926 (New York, 1932).

5. For Smoot-Hawley Act of 1930, see: Frank W. Taussig, The Tariff History of the United States (8th ed., New York, 1931) and Joseph M. Jones, Jr., Tariff Retaliation (Philadelphia, 1934).

6. Congressional Record, 71 Cong., 2 sess., 14 June 1930, 10789; Cyrenus Cole Washington Newsletter, 2 January 1930, Scrapbook 7, Cyrenus Cole Papers, State Historical Society of Iowa, Iowa City, Iowa; Cole to Walter H. Newton, 9 June 1930, Box 281, Tariff Commission file, Presidential Papers, Herbert Hoover Presidential Library, West Branch, Iowa. 
TABLE 2

House Roll Calls

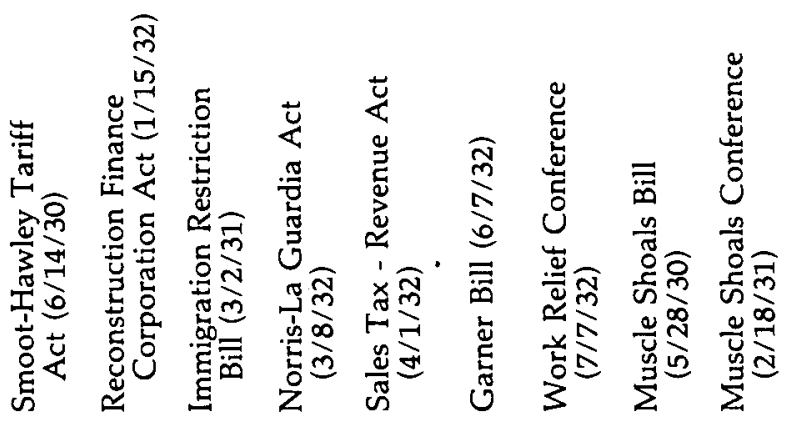

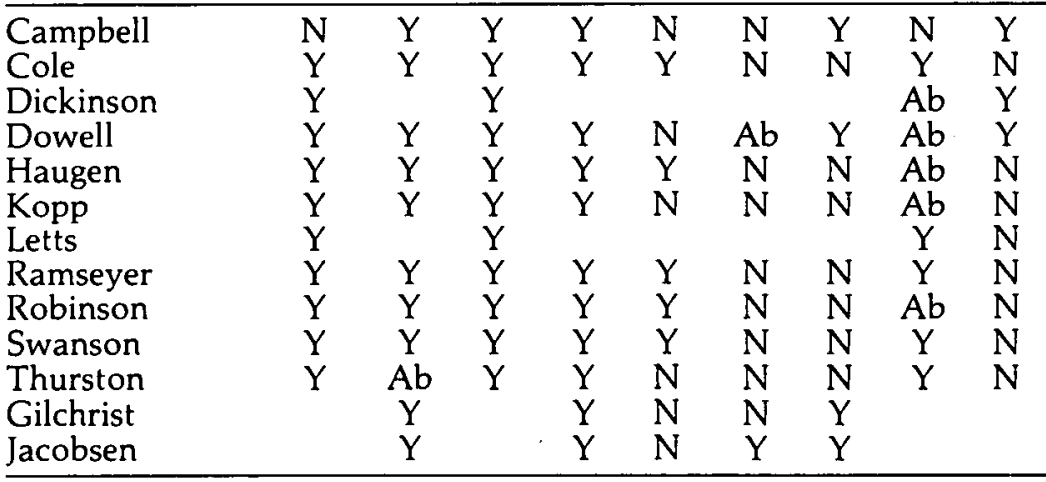

Note: $\mathrm{Y}=$ yes vote, $\mathrm{N}=$ no vote, $\mathrm{Ab}=$ abstain or absent.

Smoot-Hawley bill. The tariff measure dramatically increased duties on corn, beef, pork, fruits, poultry, eggs, lard, wool, and other farm products, better safeguarding agricultural interests. "It gives agriculture," Congressman Letts boasted, "the best rates the farmer has ever had." The Smoot-Hawley legislation, Iowa representatives argued, sheltered American producers against foreign competition and perhaps saved the jobs of native workers. "To keep the home market in large part for the home producer," Congressman Robinson stressed, "is a very vital thing." An ardent protectionist, Representative Haugen

7. Gilbert N. Haugen, "Campaign Remarks," 1930, Box 129, Gilbert N. Haugen Papers, State Historical Society of lowa; "Iowa Senators and Congressmen Discuss Tariff," Iowa Homestead, 16 May 1929, Scrapbook 9, Fred D. Letts Papers, University of Iowa Libraries, lowa City, Iowa. 
asserted, "It has restricted the importation of foreign merchandise into this country and kept American plants going. ${ }^{\prime 8}$ Politically, the nearly unanimous Republican delegation gladly empowered President Hoover to raise duties. "We have in the White House," Congressman Ramseyer contended, "a President who understands the needs of the country and is especially well equipped to deal with the great economic and moral problems that must be solved." 9

By contrast, Senators Brookhart and Steck, along with Representative Campbell, denounced the economic ramifications of the Smoot-Hawley bill. (See Table 3) The trio protested that the tariff measure benefited eastern industrialists at the expense of midwestern farmers. "'Big business,' " Brookhart charged, "has garnered extortionate profits, but it has ruined the general prosperity of the country." ${ }^{10}$ Campbell condemned the legislation as "one of those political monstrosities" placing "heavier burdens" upon the farmer and feared that it "increased protection for many of those industries" already "making fortunes." Any agricultural benefits, Steck warned, would "be more than absorbed in the increased prices the farmer will have to pay because of additional duties on the things he must buy." In addition, they insisted that tariff increments would harm American foreign trade and sharply curtail agricultural exports. "I favor a protective tariff as an established American institution," Steck declared, "but can not support a prohibitive tariff."11

Similarly, the business-oriented Reconstruction Finance Corporation Act of 1932 attracted wholehearted backing from

8. Thomas J. B. Robinson, "Tariff," 1930, Speeches file, Thomas J. B. Robinson Papers, University of Iowa Libraries; North lowa Times, 6 October 1932, in Box 129, Haugen Papers.

9. "Congressman Ramseyer Talks About the Tariff," Des Moines Register, 2 August 1929.

10. Congressional Record, 71 Cong., 2 sess., 13 June 1930, 10635; Smith W. Brookhart, Radio Address, 19 March 1932, in Congressional Record, 72 Cong., 1 sess., 21 March 1932, 6786.

11. Ed. H. Campbell, NBC Radio Address, 19 March 1930, Box 11, Ed H. Campbell Papers, University of Iowa Libraries; Campbell to Lewis L. Robbins, 19 June 1930, Box 10, Campbell Papers; Iowa Homestead, 16 May 1929. 
TABLE 3

Senate Roll Calls

\begin{tabular}{lccc}
\hline \hline & Brookhart & Steck & Dickinson \\
\hline Smoot-Hawley Tariff Act $(6 / 13 / 30)$ & $\mathrm{N}$ & $\mathrm{N}$ & \\
Reconstruction Finance Corporation & & & \\
$\quad$ Act $(1 / 11 / 32)$ & $\mathrm{N}$ & & $\mathrm{Ab}$ \\
Norris-La Guardia Act $(3 / 1 / 32)$ & $\mathrm{Y}$ & & $\mathrm{Y}$ \\
LaFollette-Costigan Bill $(2 / 16 / 32)$ & $\mathrm{Y}$ & & $\mathrm{Ab}$ \\
Wagner Bill $(6 / 10 / 32)$ & $\mathrm{Y}$ & & $\mathrm{Ab}$ \\
Work Relief Conference $(7 / 9 / 32)$ & $\mathrm{Y}$ & $\mathrm{N}$ & \\
Muscle Shoals Bill $(4 / 4 / 30)$ & $\mathrm{Y}$ & $\mathrm{Y}$ & \\
Muscle Shoals Conference $(2 / 21 / 31)$ & $\mathrm{Y}$ & $\mathrm{Y}$ & \\
\hline
\end{tabular}

Note: $\mathrm{Y}=$ yes vote, $\mathrm{N}=$ no vote, $\mathrm{Ab}=$ abstain or absent.

The Senate did not vote on Immigration Restriction Bill of 1931 or Sales Tax provision of Revenue Act of 1932.

the Iowa delegation. All Iowa representatives and Senator Dickinson, who had defeated Steck in the 1930 election, strongly favored the creation of the powerful Reconstruction Finance Corporation. The comprehensive measure allocated the RFC 500 million dollars to rescue and revive depressed banks, railroads, and building and loan associations. ${ }^{12}$

As on the tariff issue, economic considerations persuaded the lowa delegation to defend the Reconstruction Finance Corporation Act. The RFC, they predicted, would rescue collapsing business institutions and spark national economic recovery. According to Congressman Campbell, "the two million dollar Corporation, with General [Charles] Dawes at its head, will be a great help to the country at large."13 The Iowa delegation also insisted that the measure would benefit midwestern farmers by revitalizing America's distressed financial institutions and railroads. Representative Haugen, the dean of the Iowa delegation, vowed that the RFC would "give renewed

12. Congressional Record, 72 Cong., 1 sess., 15 January 1932, 2081; 11 January 1932, 1705; James S. Olson, Herbert Hoover and the Reconstruction Finance Corporation, 1931-1933 (Ames, 1977) and Gerald D. Nash, "Herbert Hoover and the Origins of the Reconstruction Finance Corporation," Mississippi Valley Historical Review 46 (December 1959): 455-468, describe the Reconstruction Finance Corporation.

13. Ed. H. Campbell, Speech, undated, Box 11, Speeches file, Campbell Papers. 
support to business, industry and agriculture." Congressman Cole, an ardent champion of big business, declared, "I hope this gigantic corporation does help the railroads-it will help us all." 14

Of the entire Iowa congressional delegation, spirited Senator Brookhart alone resisted the Reconstruction Finance Corporation Act. During floor debate, Brookhart denounced the measure as a "bolshevik bill" advantageous to large business and financial interests. "The same bankers who howl about putting the Government into business," he protested, "never hesitate to put it in for their own benefit." Brookhart vowed, "the Senate had better send the Bernard Baruchs, the [Wesley] Mitchells, and the [Robert] Lamonts back to their business" and "pass a real bolshevik bill in the interest of the people of the United States." ${ }^{15}$

ONGREss, meanwhile, debated several crucial measures assisting organized labor. In 1931 the House passed an immigration bill excluding 376,000 persons over a two-year period and sharply curtailing the European, Canadian, and Mexican quotas. Labor unions enthusiastically greeted the immigration legislation because hordes of foreigners between 1880 and 1920 had taken jobs away from native American workers by toiling for lower wages. Congress in 1932 overwhelmingly approved the Norris-La Guardia Act forbidding injunctions against certain outlawed union practices, guaranteeing jury trails by violators, and making yellow-dog contracts unenforceable in federal courts. During debate on the Revenue Act of 1932, the House crushed an amendment to levy a one year sales tax on articles of wide use and distribution by all socio-economic classes. Organized labor, which advocated increasing either

14. Haugen to F. K. Rummer, 1 February 1932, Box 37, Haugen Papers; Haugen to O. T. Knudtson, 11 January 1932, Box 37, Haugen Papers; Cole Newsletter, 18 January 1932, Scrapbook 7, Cole Papers.

15. Congressional Record, 72 Cong., 1 sess., 8 January 1932, 1493, 1496-1497; 7 January 1932, 1436. 
graduated income or property levies, denounced the sales tax because it did not alleviate the plight of poor workers. ${ }^{16}$

With economic motivations again paramount, the Immigration Restriction Bill of 1931 and the Norris-La Guardia Act of 1932 were endorsed unanimously by the Iowa congressional delegation. Alarmed over the chronic national unemployment rate, Iowa senators and representatives argued that foreigners often had stolen jobs from American workers by accepting subsistence wages. "To add 150,000 to our unemployed, by admitting that many employment seekers from foreign lands," Representative Cole warned, "might create a more serious situation than is being created by increasing the loans to former service men." According to Congressman Thurston, "If those in public life during the ten years preceding 1921 had . . . been able to see the ultimate folly of our tooliberal immigration policy there would be no unemployment today." 17 In addition, the Iowa delegation charged that immigrants disrupted the stability and order in American life. "We would have," Cole feared, "a land teaming with mobs, riots, communism and anarchy." Cole even declared "our restrictive immigration law has been our best enactment in recent years, if not since the Declaration of Independence." ${ }^{18}$ The Norris-La Guardia Act, several Iowa congressmen asserted, would obliterate economic discrimination against organized labor and guarantee workers more protection. Representative Haugen stressed "judging by the votes received and the sentiment generally expressed by practicing attorneys, legislation along the line seemed necessary." A dedicated defender of labor causes, Congressman Campbell charged that "human rights had

16. For labor measures in the Hoover era, see Schwarz, Interregnum of Despair; Irving Bernstein, The Lean Years: A History of the American Worker, 1920-1933 (Boston, 1960); Richard Lowitt, George W. Norris: The Persistence of a Progressive, 1913-1933 (Urbana, 1971); Howard Zinn, La Guardia in Congress (Ithaca, 1959); and J. Joseph Hutchmacher, Senator Robert F. Wagner and the Rise of Urban Liberalism (New York, 1968).

17. Congressional Record, 71 Cong., 3 sess., 2 March 1931, 6744, 6721; 72 Cong., 1 sess., 8 March 1932, 5511; 1 March 1932, 5019; Cole Newsletter, 18 February 1931, Scrapbook 7, Cole Papers; Lloyd Thurston, Speech, Derby Fair, 1932, Box 4, Lloyd Thurston Papers, State Historical Society of Iowa.

18. Cole Newsletter, 1 March 1928, Scrapbook 6, Cole Papers. 
been interfered with under the present method of granting injunctions." ${ }^{19}$

Unlike the immigration and Norris-La Guardia measures, however, the sales tax question fragmented the Iowa delegation. Five Iowa congressmen, along with Senator Dickinson deserted organized labor this time, lauding the oneyear sales tax method for raising federal revenue. They claimed that the levy would not only expedite balancing of the budget, but argued that it would not hurt ordinary workers. Representative Swanson proclaimed, "The important matter for consideration under all circumstances is the balancing of the budget." Congressman Cole insisted, "The tax is so light that it is not believed that any one will be seriously affected."20

On the other hand, six Iowa representatives and Senator Brookhart warned about the economic dangers of the sales tax. Adamant defenders of organized labor, they protested that the sales tax discriminated against the downtrodden working classes. Representative Campbell deplored the sales levy for "The unfairness it represents," while Senator Brookhart mainttained that "this is a tax directly upon the people, who are not able to pay for it." In lieu of a sales tax, they campaigned for increasing graduated income and property levies. "During times like these," Campbell retorted, "the rich should assume the greater portion of the taxation. Surely these men can far better assume heavy taxes." Likewise, Brookhart argued that these income and property levies would be better methods to "redistribute some of the amassed wealth of the country" and "build a solid foundation for prosperity." 21.

19. Haugen to Leo Hufschmidt, 25 March 1932, Box 37, Haugen Papers; Campbell to George T. Hatley, 28 March 1932, Box 11, Campbell Papers.

20. Congressional Record, 72 Cong., 1 sess., 1 April 1932, 7329; 31 May 1932, 11666; 16 March 1932, 6264; Cole Newsletter, 19 March 1932, Scrapbook 7, Cole Papers. House rejection of the sales tax approach dismayed the anti-labor forces within the Iowa delegation. "The debacle," Cole declared, "was the most expensive piece of legislative cowardice and bungling that I have seen since I have been in Congress." Cole Newsletter, 4 June 1932, Scrapbook 7, Cole Papers; Cole, I Remember, 515.

21. Sioux City News Release, 25 January 1932, Box 4, Campbell Papers; Brookhart, Radio Address, 19 March 1932. 
By contrast, Iowa congressmen usually repudiated federal unemployment relief measures. In June 1932, all Iowa representatives except Democrat Jacobsen rejected the controversial Garner Relief Bill. This legislation, approved by the House, would have authorized over two billion dollars for building construction, flood control projects, and rivers and harbors improvements. A month later, three Republicans joined Jacobsen in ratifying the conference report largely containing the Garner version. ${ }^{22}$

In the Senate, Brookhart clashed with Dickinson on federal work relief legislation. During 1932, Brookhart vigorously favored and Dickinson rejected the La Follette-Costigan and Wagner bills and the conference report. The La Follette-Costigan measure, crushed in February by the Senate, would have provided direct grants of 375 million dollars to states for unemployment and public works projects. The less comprehensive Wagner bill, adopted by the Senate four months later, would have permitted Reconstruction Finance Corporation loans totalling 300 million dollars to states and authorized the federal government to spend 500 million dollars for local public works projects. ${ }^{23}$

Political and economic connotations of direct national work relief upset most members of the Iowa congressional delegation. Above all, they feared that such measures would grant the federal government too much power and authority over the American people. Senator Dickinson brusquely accused the relief proposals of being "dangerous in future existence of government itself," while Congressman Cole attacked the Garner bill as "hysteria in the nth power," "demagogism in the superlative degree," and "bribery on a national scale." 24 Deploring federal assistance, they recommended instead that states and local communities furnish unemployment relief. Otherwise, critics feared that federal taxes

22. Congressional Record, 72 Cong., 1 sess., 7 June 1932, 12244; 7 July 1932, 14820. For work relief measures, see works listed in note 16.

23. Congressional Record, 72 Cong., 1 sess., 16 February 1932, 4052; 10 June 1932, 12549; 9 July 1932, 14975.

24. Cole Newsletter, 28 May 1932, Scrapbook 7, Cole Papers. 
would skyrocket. Representative Swanson attacked "the unsound and uneconomic policy of the construction of public buildings in any section of the country in times like these when our people are overburdened with taxes and are themselves in financial distress." Similarly, Congressman Haugen implored that "drastic reduction in expenditures must be made, not only in local and state expenditures, but with the Federal Government as well." 25 In addition, most lowa representatives charged that the Garner measure discriminated economically against the midwestern states. Besides denouncing the Garner proposal as the "biggest pork barrel ever devised," Cole repudiated it as "a form of bribery, of corruption, of pollution, and everything else that is bad." In a similar vein, Haugen protested that the measure meant spending "enormous" sums to construct southern projects and claimed that a few northern buildings were included "as a bait to catch the vote from the North."26

Economic factors prevailed among the minority defending federal work relief. Alarmed at the ten million jobless rate, they stressed that extensive public works projects would help alleviate the chronic national situation. "If you crowd your poor-houses," Congressman Campbell warned, "it only means additional taxes on the owners of the home and property." Along with charging that "Congress fails all the time to do its duties," Senator Brookhart asserted that work relief was only "one-tenth of what it ought to be." Federal intervention on behalf of the jobless, defenders argued, would help equalize the distribution of income. According to Brookhart, the relief appropriations were "largely collected off of large incomes and big estates and not a direct burden on ordinary people." 27

Between 1929 and 1933, Congress also disagreed over the expansion of federal competition with private enterprise. In April 1930, the Senate approved the Norris bill permitting the

25. Congressional Record, 72 Cong., 1 sess., 7 June 1932, 12249; Haugen to C. A. Hammer, 9 April 1932, Box 37, Haugen Papers.

26. Cole Newsletter, 28 May 1932; Gilbert N. Haugen, Speech, 1932, Box 129, Haugen Papers.

27. Ed H. Campbell, Speech, undated, Box 11, Campbell Papers; Congressional Record, 72 Cong., 1 sess., 10 June 1932, 12536. 
federal government to own and operate power facilities on the Tennessee River at Muscle Shoals, Alabama and construct Cove Creek Dam on the Clinch River in Tennessee. The House, however, discarded the measure, opting instead to lease the government properties at Muscle Shoals to private industry. Nine months later, the House consented to a conference report largely restoring the original Norris version. ${ }^{28}$

For a combination of political and economic reasons, the Iowa congressional delegation resoundingly remonstrated against the expansion of federal controls over Muscle Shoals. Most Iowa representatives dissented on the original Norris version, while five even urged leasing the government properties at Muscle Shoals to private industry. In February 1931, eight lowa congressmen refused to accept the ultimate conference report. ${ }^{29}$ As critics of the burgeoning federal bureaucracy, they charged that the Norris bill would allow the national government to have an unfair advantage over private power companies. Representative Cole brusquely denounced the federal operation of power plants as "somewhat Russian" and retorted "the more the government keeps its hands out of business the better for both business and the government." The Muscle Shoals project, Congressman Thurston charged, would "furnish cheap power that might be disastrous to the coal industry on which my own district is so strongly dependent. Some may call this a narrow-minded view but I believe no congressman should acknowledge leadership other than the sentiment of his constituents." ${ }^{\prime 30}$ As on the Garner relief bill, they complained that the Muscle Shoals measure would benefit the South at the expense of the Middle West and other geo-

28. Congressional Record, 71 Cong., 2 sess., 4.April 1930, 6511; 28 May 1930, 9767; 71 Cong., 3 sess., 18 February 1931, 5570-5571; 21 February 1931, 5716. In May 1930, Representatives Dickinson, Dowell, Haugen, Kopp, and Robinson abstained on the Muscle Shoals bill. For the Muscle Shoals controversy, see: Lowitt, Norris, 457-463; Preston J. Hubbard, Origins of the TVA: The Muscle Shoals Controversy, 1920-1932 (New York, 1961).

29. Congressional Record, 71 Cong., 2 sess., 28 May 1930, 9767; 71 Cong., 3 sess., 18 February 1931, 5570-5571.

30. Cole Newsletter, 3 April 1930, Scrapbook 7, Cole Papers; Lloyd Thurston, Speech, Monroe County, Iowa, 1934, Box 4, Thurston Papers. 
graphical regions. "So far as Iowa is concerned," Cole contended, "Muscle Shoals is about as important as. the man in the moon. Southern politicians who still believe that a federal government owes them something for Civil War losses are trying to maneuver the United States into a position of furnishing their planters with fertilizers made at government expense." Heavy financial burdens on the American taxpayer, critics feared, would accrue from the federal operation of power facilities. "No cheap fertilizer can be made at the Shoals," Cole claimed, "unless the federal treasury is looted to do so." ${ }^{131}$

Economic arguments prevailed among the few Iowa congressmen defending the Muscle Shoals public power concept. From the outset, Senators Brookhart and Steck and Representative Campbell strongly favored the Norris bill letting the government operate the power facilities. After abstaining originally, Congressmen Dowell and Dickinson joined Campbell in endorsing the conference report. Since private power companies might ignore the public interest in developing the Muscle Shoals region, these members argued that federal government operation of the facilities would better guarantee consumer protection. Representative Dickinson warned, "if we cannot regulate power trusts, we will not be successful in either owning them or operating them as a Government. A definite effort should be made to devise a joint state and Government supervisory policy whereby the public interest would be protected against the power organizations of the country. ${ }^{\prime 32}$

A lthough almost exclusively Republican, the Iowa delegation ranged from progressive to conservative on the above economic issues. Representatives Campbell and Gilchrist, along with Senator Brookhart, boldly backed progressivism, aligning with organized labor against big business, demanding massive federal relief for the jobless, and welcoming government

31. Cole Newsletter, 14 January 1931, Scrapbook 7, Cole Papers.

32. Congressional Record, 71 Cong., 2 sess., 4 April 1930, 6511; 28 May 1930, 9767; 71 Cong., 3 sess., 18 February 1931, 5570-5571; 21 February 1931, 5716; Lester J. Dickinson, CBS Radio Speech, 31 March 1931, Box 530, Dickinson file, Presidential Papers, Hoover Library. 
competition with private enterprise. Congressman Dowell, a moderate progressive representing Des Moines, backed organized labor except on the sales tax and defended both work relief and federal operation of the Muscle Shoals facilities. In the moderate camp, Representatives Dickinson, Haugen, and Kopp supported measures aiding business and organized labor and resisted federal unemployment relief. By contrast, Congressmen Cole, Letts, Ramseyer, and Swanson usually aligned with conservatives on Capitol Hill. They not only defended big business over organized labor, but attacked direct federal work relief programs and expanding federal competition with private industry.

The Iowa congressional delegation largely echoed President Hoover's sentiments on legislation aiding business. An advocate of very limited federal government intervention in the economy, Hoover endorsed both the Smoot-Hawley and Reconstruction Finance Corporation acts. Nine Iowa congressmen agreed with the president on both issues, while Senator Brookhart alone consistently repudiated the president's views. Representative Campbell, who split with Hoover over the tariff, admitted, "It is not any easy matter to vote against the leadership and the rest of the delegation. I refuse to be a rubber stamp politician for any group or any organization. I've been sent to Washington to do what I can for the northwestern Iowa district and I'm going to do it." ${ }^{33}$

On the other hand, the Iowa congressional delegation responded more enthusiastically than Hoover toward legislation helping organized labor. Although favoring the Immigration Restriction Bill of 1931, the president almost vetoed the Norris-La Guardia Act and assiduously defended the anti-labor sales tax. Hoover feared that the Norris-La Guardia Act might make labor unions too powerful and argued that graduated income and property taxes discriminated against wealthier economic classes. Senator Brookhart and Representatives Campbell, Dowell, Gilchrist, Haugen, Kopp, and Thurston aligned more often than the president with organized

33. Spencer News Herald, 4 July 1932; Campbell to Robbins, 19 June 1930, Campbell Papers. 
labor. They not only welcomed the Norris-La Guardia Act, but strenuously objected to the sales tax. Congressman Campbell lauded labor unions as "the life blood which brings us the American Standard of Living" rescuing "from the dark doors of industrial slavery many men and women." ${ }^{34}$ By contrast, Senator Dickinson and Representatives Cole, Ramseyer, Robinson, and Swanson were the only members of the Iowa delegation sharing Hoover's more conservative views on labor legislation. Cole, who represented the district in which Hoover was born, adamantly defended the president. According to Cole, "no man has ever done greater or better work in such a high office than Mr. Hoover has been doing. Some day, when we are farther along on the way to recovery, the world over, we will realize what he has been doing and praise and honor him for it." 35

On federal work relief measures, the Iowa congressional delegation largely concurred with Hoover. The president despised both the La Follette-Costigan and Garner bills, demanding instead the individuals, private organizations, communities, and states coordinate unemployment relief programs. In July 1932, Hoover vetoed the conference report and particularly attacked the Garner "pork barrel" provisions. ${ }^{36}$ On these controversial issues, Senator Dickinson and Representatives Cole, Haugen, Kopp, Ramseyer, Robinson, Swanson, and Thurston rallied behind the president. Hoover, however, did not win the support of Congressmen Campbell, Dowell, and Gilchrist and especially Senator Brookhart, all of whom demanded an extensive infusion of federal assistance for the jobless.

Similarly, the Muscle Shoals controversy saw a majority of the lowa congressional delegation in accord with the president.

34. Ed. H. Campbell, Speech, 1 September 1930, Box 11, Campbell Papers.

35. Cole Newsletter, 7 January 1931, Scrapbook 7, Cole Papers. Other Iowa representatives defended Hoover's performance as chief executive. See Fred D. Letts to constituents, 31 October 1930, Scrapbook 2, Letts Papers; Lester J. Dickinson, Speech, Donnelson, Iowa, 27 September 1930, Box 140, Haugen Papers.

36. Schwarz, Interregnum of Despair, 162-172; Warren, Hoover and Great Depression, 205-207. 
TABLE 4

House Roll Call Votes on Economic Issues

\begin{tabular}{lccc}
\hline \hline Issue & Date & $\begin{array}{c}\text { Percentage Iowa } \\
\text { Delegation For }\end{array}$ & $\begin{array}{c}\text { Percentage Entire } \\
\text { House For }\end{array}$ \\
\hline Smoot-Hawley Tariff & $6 / 14 / 30$ & 91 & 59 \\
$\begin{array}{l}\text { Reconstruction Finance } \\
\quad \text { Corporation }\end{array}$ & $1 / 15 / 32$ & 100 & 86 \\
Immigration Restriction & $3 / 2 / 31$ & 100 & 78 \\
Norris-La Guardia & $3 / 18 / 32$ & 100 & 96 \\
Sales Tax & $4 / 1 / 32$ & 45 & 40 \\
Garner Relief & $6 / 7 / 32$ & 10 & 54 \\
Work Relief (confer.) & $7 / 7 / 32$ & 36 & 56 \\
Muscle Shoals (initial) & $5 / 28 / 30$ & 83 & 63 \\
Muscle Shoals (confer.) & $2 / 18 / 31$ & 27 & 59 \\
\hline
\end{tabular}

A defender of private enterprise and voluntarism, Hoover boldly denounced the direct federal ownership and operation of the Muscle Shoals properties. In July 1931, Hoover issued a stinging veto of the final conference report containing the Norris version. "This is not liberalism," Hoover declared, "it is degeneration." Eight lowa representatives sided with the president in remonstrating against federal operation of the Muscle Shoals plant, while Senators Brookhart and Steck and Representatives Campbell, Dickinson, and Dowell demanded public control. ${ }^{37}$

The Iowa congressional delegation, to a surprising extent, mirrored national legislative sentiment. Although serving rural constituents primarily and comprising relatively few Democrats, Iowa senators and representatives reacted in a more progressive manner than anticipated to national economic problems. Iowa congressmen surpassed the House as a whole in the degree of enthusiastic support for legislation aiding business and organized labor. (See Table 4) By contrast, Iowa representatives lagged behind national sentiment only on the unemployment relief and public power questions.

Several conclusions might be drawn. During the Hoover era, Iowa senators and representatives zealously defended federal assistance to business and organized labor. On the other

37. Lowitt, Norris, 463-464; Congressional Record, 71 Cong., 3 sess., 21 February 1931, 5716. 
hand, it rejected aid to the jobless by the federal government and public operation of the Muscle Shoals power facilities. Bloc voting normally occurred on business or labor measures, most notably on the Reconstruction Finance Corporation and NorrisLa Guardia acts and the Immigration Restriction bill. Iowa representatives, though, split sharply on the sales tax and lacked consensus on the work relief and Muscle Shoals issues. The attitudes of individual members fluctuated considerably, ranging from the rabid progressivism of Brookhart, Campbell, and Gilchrist to the marked conservatism of Cole, Letts, Ramseyer, and Swanson.

Economic factors usually overshadowed political considerations as voting determinants among the Iowa congressional delegation. Spirited advocates of business and labor legislation, Iowa senators and representatives sought to revive economic prosperity across the nation and especially for farmers from the Middle West. Iowa farmers, already suffering serious economic difficulties in the 1920s, continued to experience a drastic decline in prices for their products. Business revival and tariff increases, the Iowa delegation argued, would spark agricultural recovery. Iowa senators and representatives backed legislation aiding urban workers in hopes that organized labor would reciprocate on agricultural measures. Political and economic determinants both affected the voting behavior of the Iowa congressional delegation on the work relief and Muscle Shoals questions. Fearful that these measures would increase taxes, Iowa congressmen also charged that the federal government would seize too much power and warned that other geographical sections would derive greater benefits than the Middle West.

Finally, the Iowa congressional delegation exhibited more progressive attitudes than Hoover on these crucial economic issues. Progressive sentiments of Iowa senators and representatives flourished most readily on labor legislation, but several members also were more receptive than the president to federal work relief and government operation of the Muscle Shoals power facilities. Business measures, however, saw widespread cooperation between the Iowa congressional delegation and Hoover. 
Copyright of Annals of Iowa is the property of State of Iowa, by \& through the State Historical Society of Iowa and its content may not be copied or emailed to multiple sites or posted to a listserv without the copyright holder's express written permission. However, users may print, download, or email articles for individual use. 